\title{
Differences between the sagitta, lapillus and vertebra in estimating age and growth in juvenile Mediterranean dolphinfish (Coryphaena hippurus)*
}

\author{
BEATRIZ MORALES-NIN ${ }^{1}$, MIRELLA DI STEFANO ${ }^{2}$, ANTONIO POTOSCHI ${ }^{3}$, \\ ENRIC MASSUTÍ ${ }^{4}$, PIETRO RIZZO ${ }^{2}$ and SALVATORE GANCITANO ${ }^{2}$ \\ ${ }^{1}$ C.S.I.C./U.I.B.- Institut Mediterrani d'Estudis Avançats, Campus Universitari, 07071 Palma de Majorca, Spain. \\ E-mail: beatriz.morales@ba.ieo.es \\ ${ }^{2}$ C.N.R.- Istituto di Tecnologia della Pesca e del Pescato, Via Luigi Vaccara 61, 91026 Mazara del Vallo (TP), Italy. \\ ${ }^{3}$ Dipartimento di Biologia Animale ed Ecologia Marina, Università di Messina, Salita Sperone 31, \\ 98166 S.Agata (ME), Italy. \\ ${ }^{4}$ IEO- Centre Oceanogràfic de les Balears, Moll de Ponent s/n, P.O. Box 291, 07080 Palma de Majorca, Spain.
}

\begin{abstract}
SUMMARY: The otoliths (sagittae and lapilli) and the vertebral centra were evaluated as ageing structures in dolphinfish age 0 juveniles (17.2-72 cm FL) caught in the seasonal small-scale fisheries of Majorca and Sicily (western and central Mediterranean). Different structure preparation techniques were also tested. Mounting and polishing lapilli for preparing frontal sections required significantly less processing time than for the sagittae. The increments in lapillus were clearly visible from the primordium to the otolith margin, whereas the intermediate zone in the sagittae was more opaque and prevented the detection of all the increments. The back-calculated hatchdates for otolith ages showed a good correlation with the species reproduction in the area and provided indirect validation for the age determination. The vertebrae centra showed increments with higher periodicity than seasonal. A test of symmetry on the ages derived from the sagitta and vertebra of the same fish indicated that the vertebra significantly underestimated the age. Considering the structure processing time and increment definition, as well as the age-length relationships obtained, it was concluded that the lapilli were the best ageing structure for juvenile dolphinfish. However, validation experiments should be carried out before the accuracy of this method can be determined.
\end{abstract}

Key words: age determination, otoliths, daily increments, vertebral centra, growth, Coryphaena hippurus, Mediterranean.

\section{INTRODUCTION}

Several authors have studied the age and growth of dolphinfish (Coryphaena hippurus) (Pisces: Coryphaenidae) using different methods. These include the studies of Beardsley (1967) and Rose and Hassler (1968) in western Atlantic waters using the annulae in scales, and those of Oxenford and Hunte (1983), Uchiyama et al. (1986) and Massutí

\footnotetext{
*Received February 3, 1998. Accepted January 20, 1999.
}

et al. (1999) using daily increments in otoliths of specimens from the western central Atlantic, Hawaiian and Mediterranean waters respectively. Also, studies from modal progression in length-frequency distribution have been applied to this species in Taiwan (Wang, 1979) and the Lesser Antilles (Oxenford and Hunte, 1983; Murray, 1985). Torres and Pauly (1991) calculated by length-frequency analysis its growth parameters in southern Africa. Some studies of growth of fish of known age reared in captivity have also been made (Hassler and Hogarth, 
TABLE 1. - Summary of the dolphinfish bony structures used in age determination: number of samples studied, fish fork length (FL) range and the laboratories by area carrying out the studies (Majorca: IMEDEA: Institut Mediterrani d'Estudis Avançats; COB: Centre Oceanogràfic de les Balears; East Sicily: UM: Universitá di Messina; West Sicily: ITPP: Istituto di Tecnologia della Pesca e del Pescato).

\begin{tabular}{|c|c|c|c|c|c|c|}
\hline \multirow[t]{2}{*}{ Ageing structure } & \multicolumn{2}{|c|}{ Number aged } & \multicolumn{2}{|c|}{ Length range $(\mathrm{cm})$} & \multirow[t]{2}{*}{ Laboratory } & \multirow[t]{2}{*}{ Area } \\
\hline & Females & Males & Females & Males & & \\
\hline Sagittae otoliths & 73 & 52 & $19-58.5$ & $16.5-58$ & IMEDEA/COB & Majorca \\
\hline Sagittae otoliths & 198 & 130 & $18.2-72$ & $17.2-64.5$ & UM & East Sicily \\
\hline Lapilli otoliths & 289 & 142 & $26-53$ & $27-53$ & ITPP & West Sicily \\
\hline Vertebrae & 198 & 130 & $18.2-72$ & $17.2-64.5$ & UM & East Sicily \\
\hline
\end{tabular}

1977; Szyper et al., 1984; Ostrowski et al., 1989; Benetti et al., 1995).

The objective of the present paper was to assess the age and growth patterns of juvenile dolphinfish using different bony structures. For this purpose, the sagittae and lapilli otolith microstructures were studied and age and growth were estimated using vertebral and otolith increment counts. These studies focused on the juvenile fish, which are the objective of the Mediterranean small-scale fishery, using fish aggregation devices in Sicilian and Majorcan waters from summer to autumn.

\section{MATERIAL AND METHODS}

During the 1995 and 1996 fishing seasons, juveniles selected to cover the length size distribution of both sexes were obtained from Sicilian and Majorcan catches. In the laboratory, the fork length (FL) of each fish was measured to the nearest millimetre, with the total weight (accurate to the nearest $0.1 \mathrm{~g}$ ) and sex also being recorded. Table 1 summarises the number of samples for each ageing material (lapilli, sagittae and vertebrae), the fish length range and the laboratory carrying out the study.

\section{Sagittae preparation and reading}

The sagittae were read using two methods. In IMEDEA laboratory the sagittal otoliths $(n=212)$ were embedded in heat hardening epoxy resin, slightly slanted, in order to obtain a section from the core to the dorsal side. They were then ground and moistened with immersion oil to improve their clarity before reading. Sequential grinding was accomplished with a graded series of carborundum grits and final polishing with $0.3 \mu \mathrm{m}$ alumina paste. Otoliths were read under a light microscope, coupled to a high-resolution video camera and monitor system, following standard procedures (Campana and Neilson, 1985; Morales-Nin, 1992). Growth increments were counted from the core to the edge of the antirostrum (Fig. 1). Otoliths were read independently by two readers, from CSIC/UIB and from $\mathrm{COB}$, and the results were accepted only if the read-

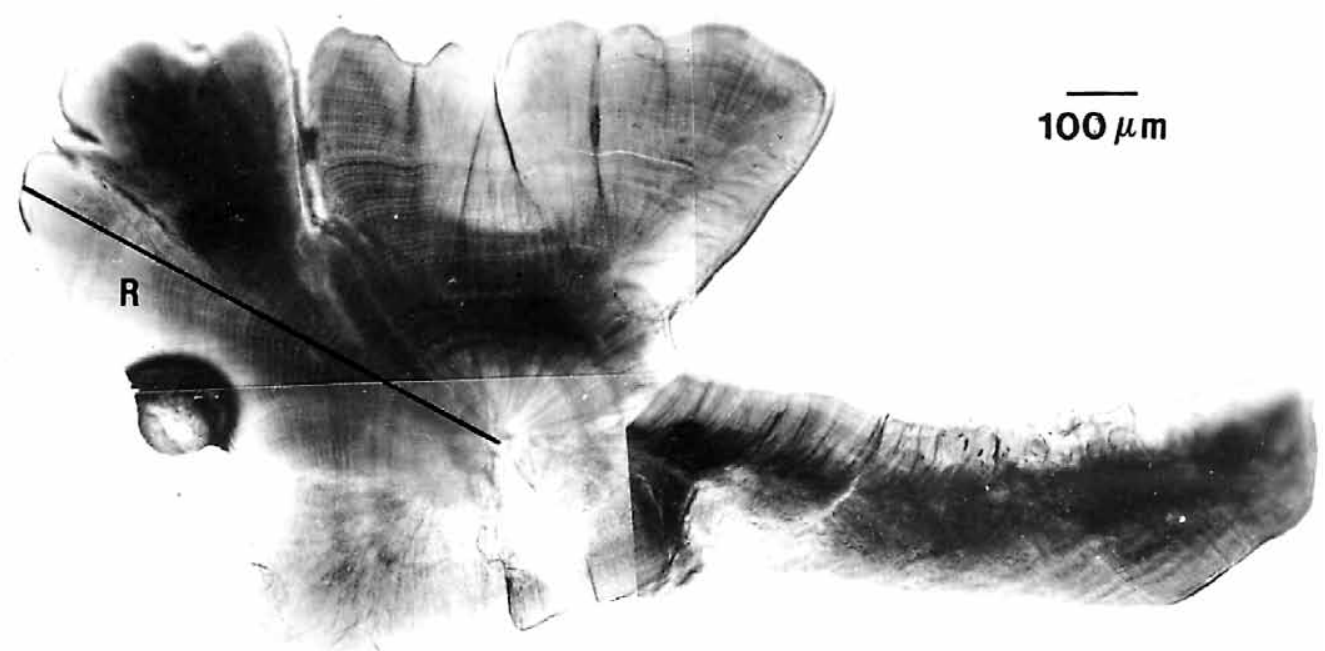

FIG. 1. - Frontal section of a dolphinfish sagitta showing the reading radius (R) and an opaque zone in the intermediate otolith structure. 


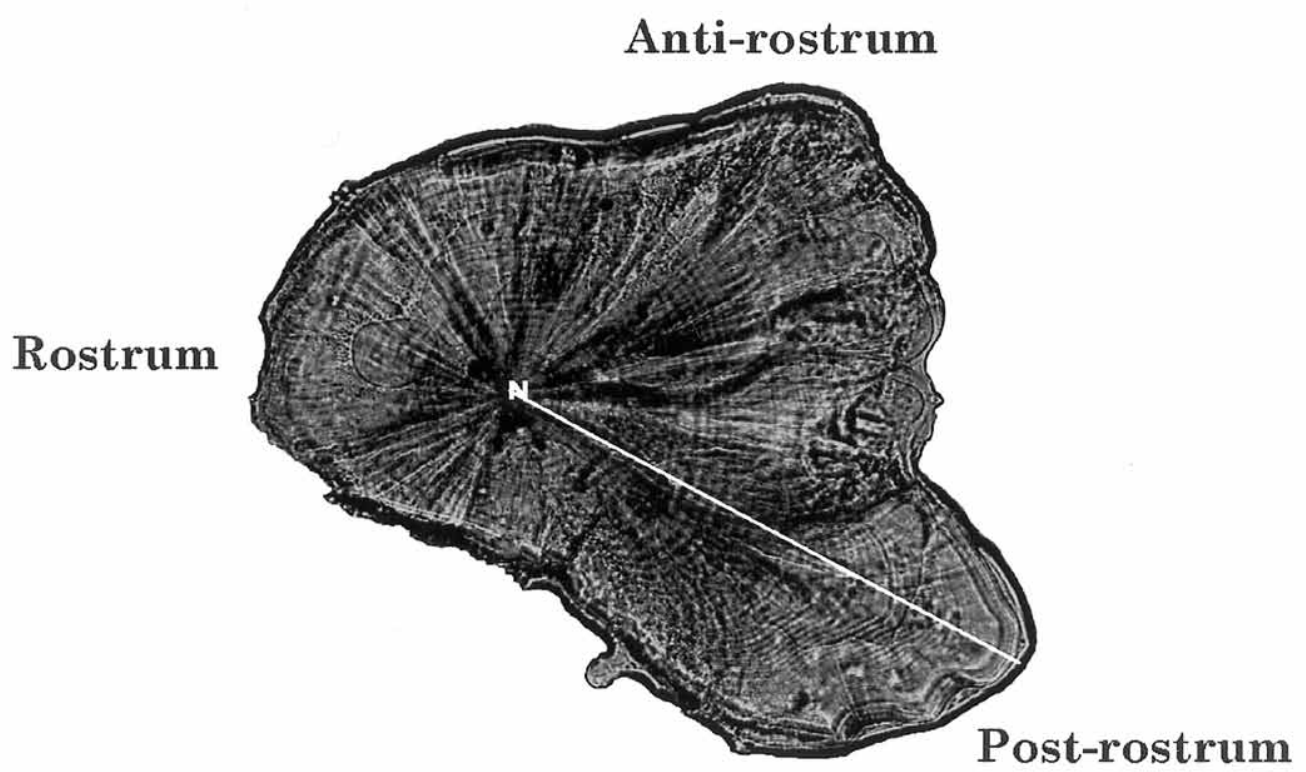

FIG. 2. - Frontal section of a dolphinfish lapillus showing the reading radius (line) and the nucleus (N).

ings were coincident or the difference in the number of increments between the readings was $<5 \%$. Growth increments were counted at 500x and verified at $1000 x$.

In Messina University the sagittae were mounted on a slide using Eukitt as the mounting medium and they were polished as already described for the Majorca laboratory. Then the otoliths were removed with xylol and mounted on a fresh slide with methyl benzoate and a cover slide. The otoliths were read under a light microscope at magnifications of 100x and 400x. Incremental counts were made beginning at the first clearly defined mark that encircled the primordium. This mark defines the outer edge of the nucleus.

\section{Lapilli preparation and reading}

The lapilli were mounted on slides with their internal side facing up, using Protexx as a mounting medium, following the methodology developed for cephalopod statoliths (Jereb et al., 1996). Repositioning of the otoliths with a needle ensured the correct otolith orientation with respect to the polishing plane. Grinding was done by hand using wet sandpaper of 10-12 mm grit. The process was controlled frequently under the microscope. Once the reading plane was reached, the otoliths were washed, a drop of Canada Balsam and a cover slide were placed on top and they were dried at $100^{\circ} \mathrm{C}$ for one hour.

The lapilli were read with a microscope at $400 \mathrm{x}$ magnification. An ocular micrometer was used to determine the increment width, and following the growth pattern identify the increments (Spratt, 1978). The increments were read along the maximum radius (Fig. 2).

\section{Vertebrae preparation and reading}

The last four vertebrae were removed by cutting the tail off the fish. The tails were deep-frozen and within three months the vertebrae centra were cleaned and prepared. After de-freezing the vertebrae were boiled and cleaned from tissues. The neural and hemal spines were cut. The intact centra were cleaned of gelatinous tissue by scratching gently and were stained with red alizarin in a solution of $\mathrm{NaOH}$ and glycerine for 4-8 hours. It was important to prepare the vertebrae before they had been frozen for three months in order to avoid degradation. In addition, care was taken to ensure that the centra surface of the vertebrae did not come into contact with water or air before being stained. After staining, the vertebrae were washed and air-dried. The vertebrae of the bigger fish were cut transversally.

The vertebral increments were enumerated from the centrum to the distal edge (Fig. 3). The reading was carried out with a microscope at 20x and 100x magnifications, with reflected light and with the vertebrae either dry or covered with clove oil.

\section{Statistical analysis}

A two way contingency table was made with the data set from the ages obtained by reading the sagit- 


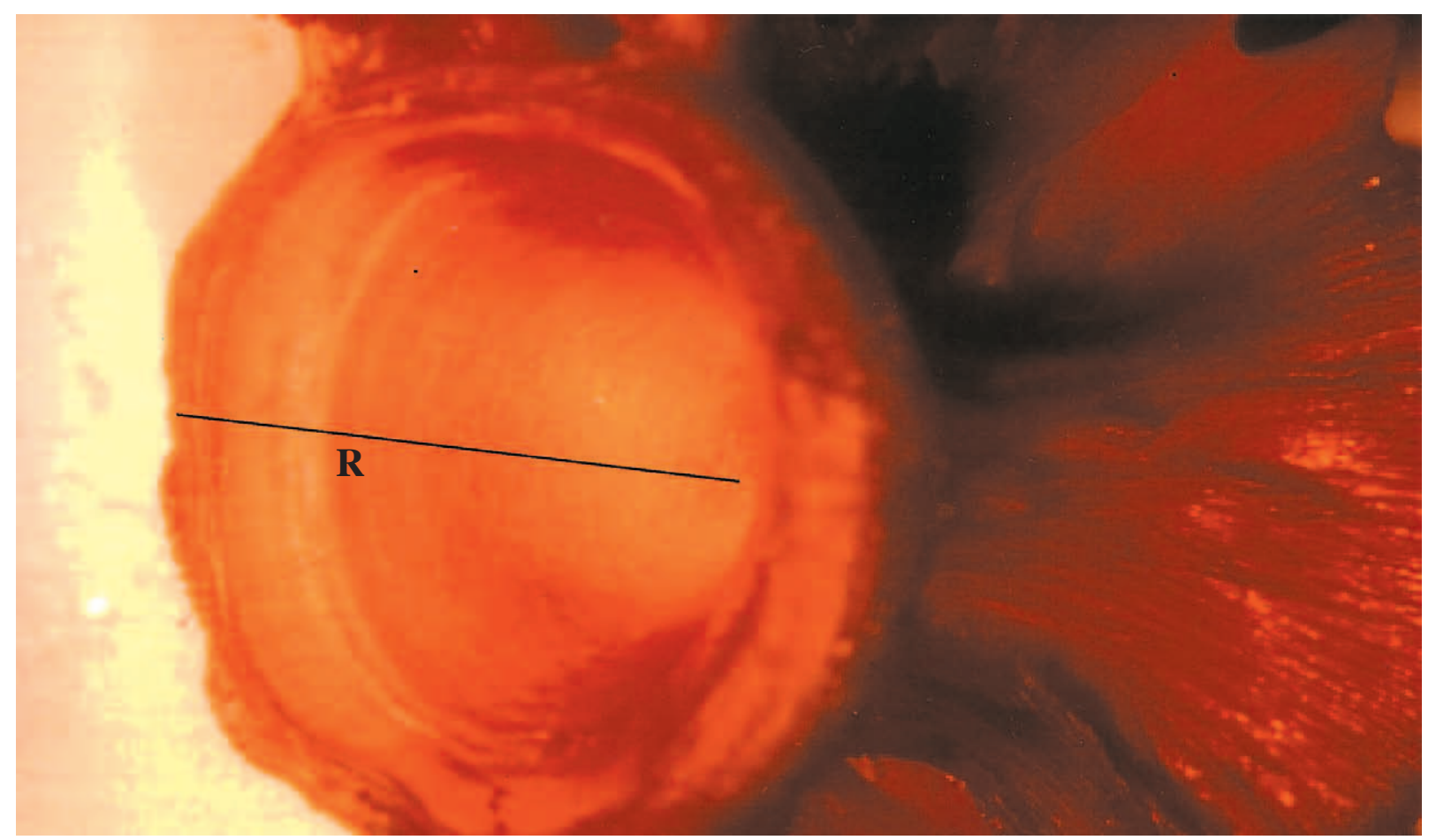

FIG. 3. - Stained dolphinfish vertebra showing the reading radius (R).

tae and vertebrae of the same fish, in order to carry out a symmetry test. A $\chi^{2}$ test was used to determine whether the age differences using the two methods were significant (Hoenig et al., 1995). The ages obtained for different fish using the lapillus and sagitta were compared by sex in relation to fish length.

An indirect comparison method was obtained by backcalculation of hatchdates from the date of capture and the age in days. Comparing these data with the periods of reproduction of dolphinfish in Mediterranean waters (Massutí and Morales-Nin, $1995,1997)$ allowed the suitability of the age determination method to be tested.

The von Bertalanffy growth parameters $\left(\mathrm{L}_{\infty}, \mathrm{k}, \mathrm{t}_{0}\right)$ were estimated from age-length relationships obtained by vertebrae and otolith readings using the FISHPARM programme (Prager et al., 1987). As $\mathrm{L}_{\infty}$ and $\mathrm{k}$ are inversely correlated, the growth performance index $\left(\Phi=2 \cdot \log \mathrm{L}_{\infty}+\log \mathrm{k}\right)$ was employed to compare growth rates (Munro and Pauly, 1983).

\section{RESULTS}

The sagittae of dolphinfish were small relative to fish size. In addition, they were generally butterflyshaped, although they displayed different morphological patterns with ontogenic development. They had a well-defined rostrum and antirostrum (Fig. 1), which became more pronounced in larger fish. Under the light microscope the otoliths revealed a pattern of alternating light and dark concentric increments surrounding a nucleus, deposited in the earliest stages of development. This central core area was well defined without an accessory nucleus. At around 60 increments from the core, an opaque zone made the enumeration of the increments difficult (Fig. 1). The age range determined from the sagittae in Majorca was 53 to 173 increments for females and 46 to 176 for males, from fish ranging between 16.5 to $58.5 \mathrm{~cm}$ FL. In Sicily, the age range was from 41 to 212 for females and 38 to 212 for males, from fish of 17.2 to $72 \mathrm{~cm}$ FL.

The lapilli were almond shaped with the core placed towards the anterior part. The increments were clearly differentiated along the maximum growth radius (Fig. 2). The age range obtained from their interpretation was 74 to 135 increments for females and 73 to 136 for males, which corresponded to a length range of between 26 and $53 \mathrm{~cm}$ FL.

The vertebral increments appeared clearly (Fig. 3 ), with a range of increments from 30 to 200 for males and 30 to 199 for females for the same length range as the Sicilian sagittae.

The relationship between FL and the number of increments in the sagittae and vertebrae had a ten- 

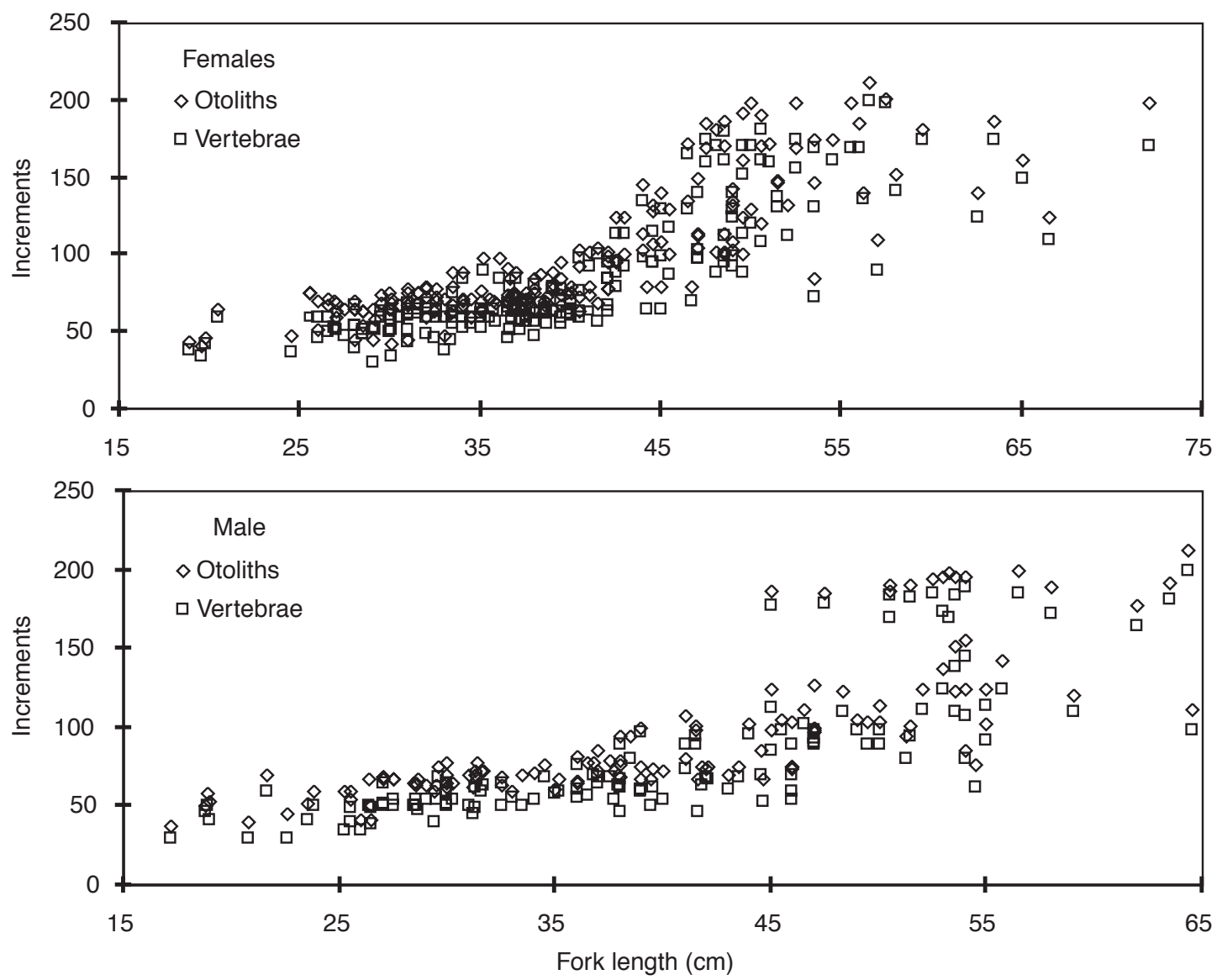

FIG. 4. - Plot of the number of rings in otoliths and vertebrae versus fork length from Sicilian dolphinfish.

dency to show lower ages using vertebrae but an increase in the dispersion values with length (Fig. 4). Sexual dimorphism in relation to growth was also evident.

The symmetry test carried out with the sagittae and vertebrae ages of the same fishes showed clear differences between the two sets of data $(\chi<0.05)$ and for both sexes (Table 2a, b), with the vertebrae giving lower ages than the sagittae. As the daily nature of the increments in the juvenile fish otoliths has been validated (Massutí et al., 1999), the vertebrae were considered inadequate for ageing juvenile fish and the remaining tests were performed with otoliths.

The relationship between FL and the number of increments showed concordance between readings for lengths below $45 \mathrm{~cm}$, with a marked increase in the scatter of points in bigger fish (Fig. 5). The increase in dispersion with age was more marked for males than for females.

To determine whether a trend was apparent in the age length relationships, the residuals of the linear plot were analysed (Fig. 6). The residuals showed an

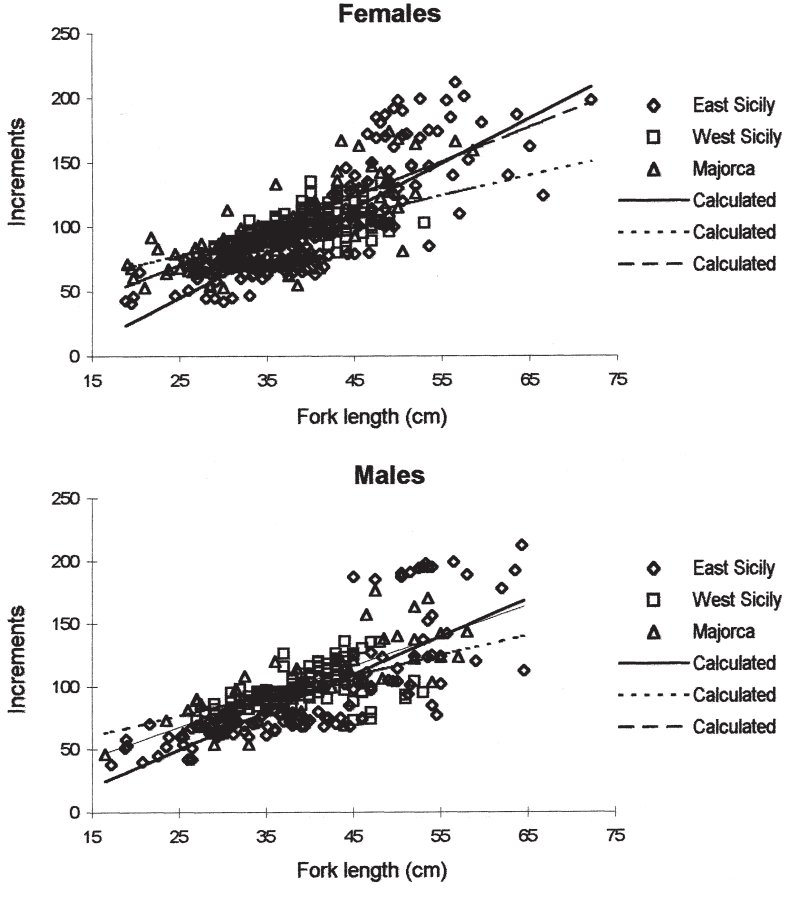

FIG. 5. - Relationship between fork length and the number of increments for both study areas and for sagittae (Majorca and eastern Sicily) and lapilli (western Sicily). 
TABLE 2. - Number of increments for reading the sagitta and vertebra of the same fish ( $\mathrm{n}=198$ females; $\mathrm{n}=130$ males). OTO: otolith reading; VER vertebra reading
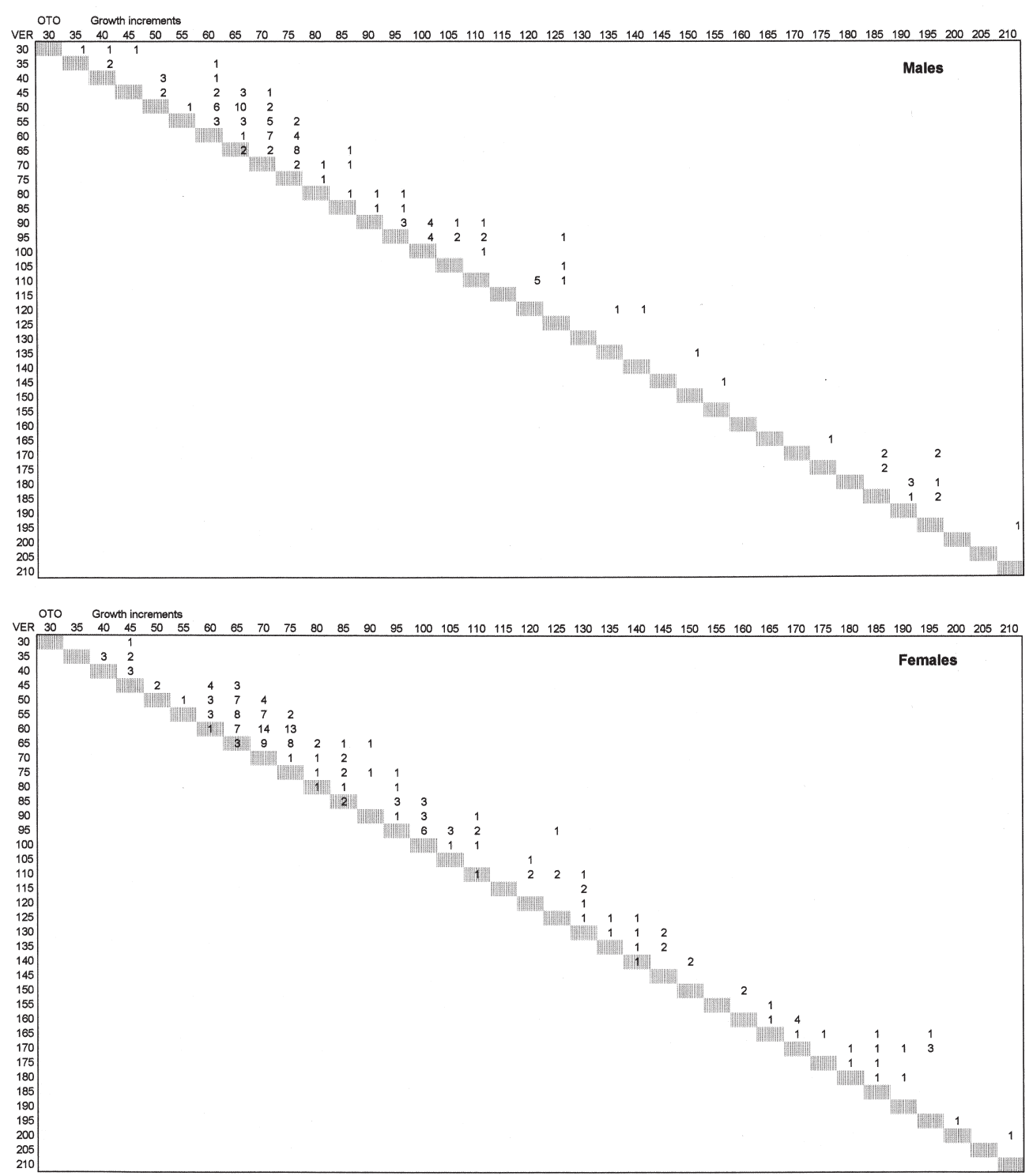

TABLE 3. - Linear relationships and comparison of the slope between the fork length and the number of increments.

\begin{tabular}{|c|c|c|c|c|c|}
\hline Area & Sex & Otolith & Equation & $\mathrm{n}$ & $\mathrm{R}$ \\
\hline $\begin{array}{l}\text { East Sicily (ES) } \\
\text { West Sicily (WS) } \\
\text { Majorca (M) } \\
\text { East Sicily } \\
\text { West Sicily } \\
\text { Majorca }\end{array}$ & $\begin{array}{l}\text { females } \\
\text { females } \\
\text { females } \\
\text { males } \\
\text { males } \\
\text { males }\end{array}$ & $\begin{array}{l}\text { sagitta } \\
\text { lapillus } \\
\text { sagitta } \\
\text { sagitta } \\
\text { lapillus } \\
\text { sagitta }\end{array}$ & $\begin{array}{l}y=-41.9129+3.4759 x \\
y=39.2022+1.5484 x \\
y=3.5911+2.6700 x \\
y=-25.1094+2.9940 x \\
y=36.5308+1.6031 x \\
y=7.1979+2.4213 x\end{array}$ & $\begin{array}{c}198 \\
289 \\
73 \\
130 \\
142 \\
52\end{array}$ & $\begin{array}{l}0.82 \\
0.67 \\
0.79 \\
0.79 \\
0.61 \\
0.81\end{array}$ \\
\hline Area & Sex & $\mathrm{b}$ & Error & Variance & $\mathrm{P}$ \\
\hline $\begin{array}{l}\text { WS vs ES } \\
\text { WS vs } M \\
\text { ES vs } M \\
\text { WS vs ES } \\
\text { WS vs } M \\
\text { ES vs } M\end{array}$ & $\begin{array}{l}\text { females } \\
\text { females } \\
\text { females } \\
\text { males } \\
\text { males } \\
\text { males }\end{array}$ & $\begin{array}{l}3.4759 \\
1.5484 \\
2.67 \\
2.994 \\
1.6031 \\
2.4213\end{array}$ & $\begin{array}{l}0.1704 \\
0.1014 \\
0.2473 \\
0.2082 \\
0.1827 \\
0.2501\end{array}$ & $\begin{array}{l}0.02903 \\
0.01028 \\
0.06116 \\
0.04335 \\
0.03338 \\
0.06255\end{array}$ & $\begin{array}{l}<0.001 \\
<0.001 \\
<0.01 \\
<0.001 \\
<0.01 \\
>0.05 * *\end{array}$ \\
\hline
\end{tabular}

** not different 
Females
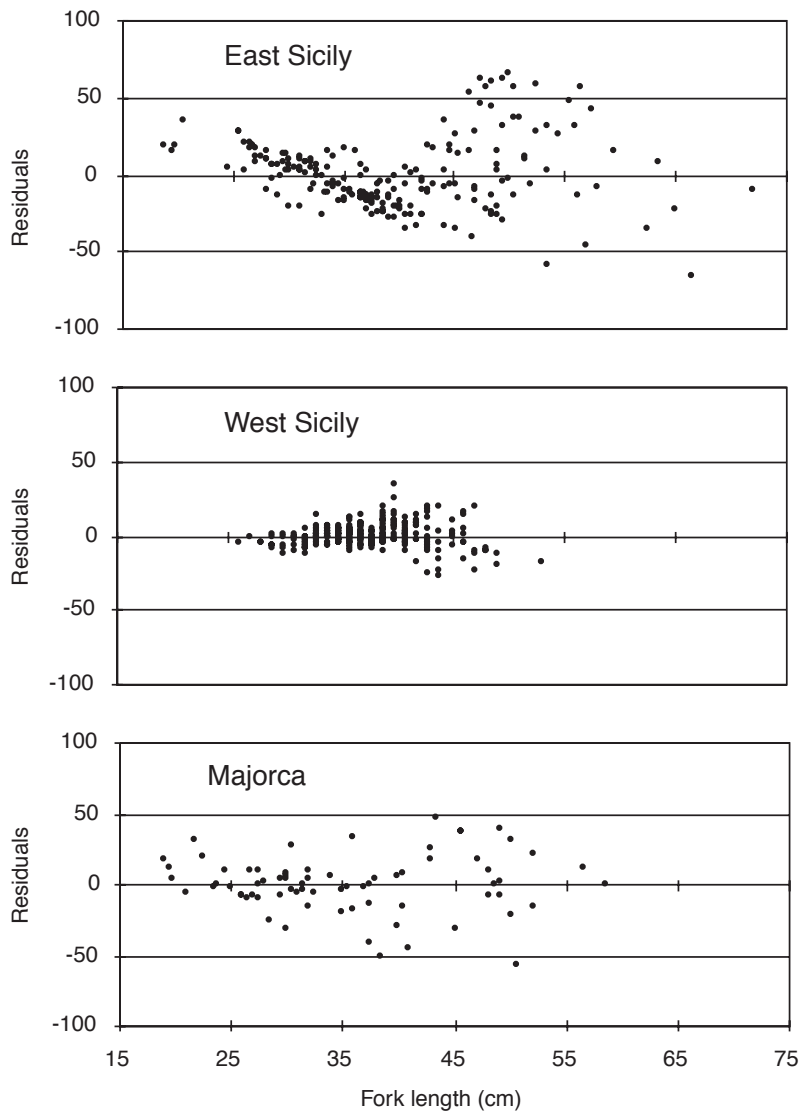

Males
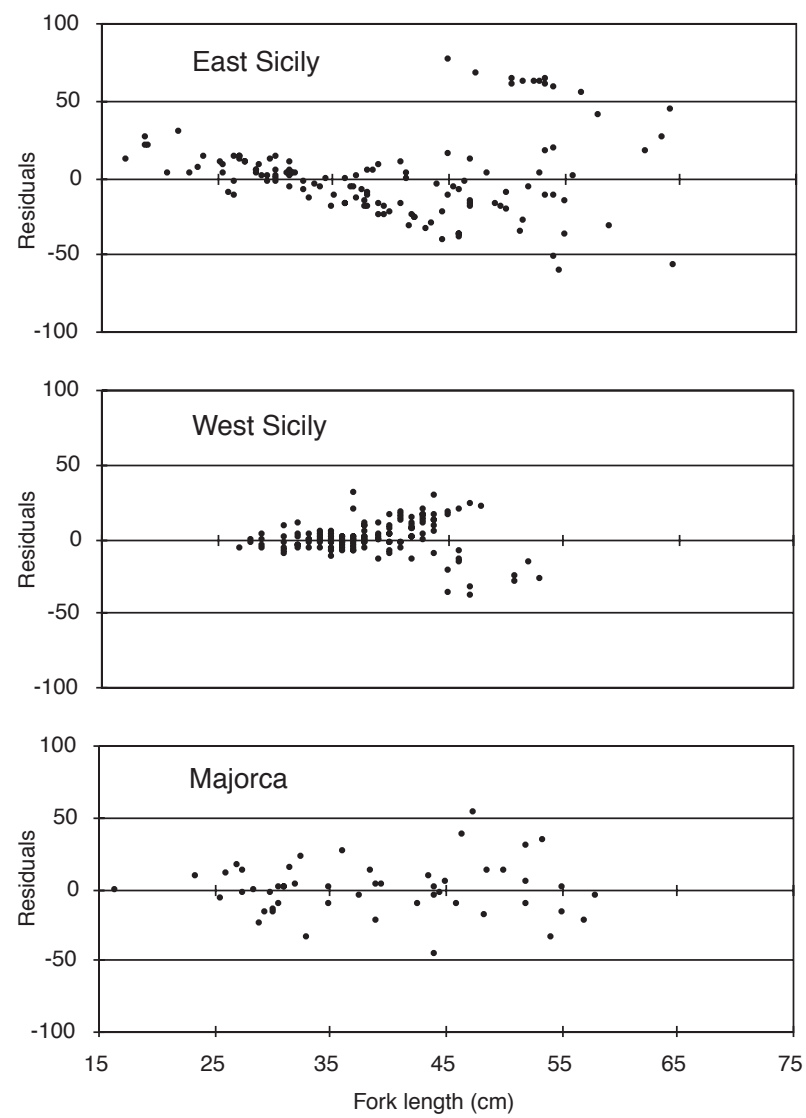

FIG. 6. - Plot of the residuals of the linear relationship of Figure 5.

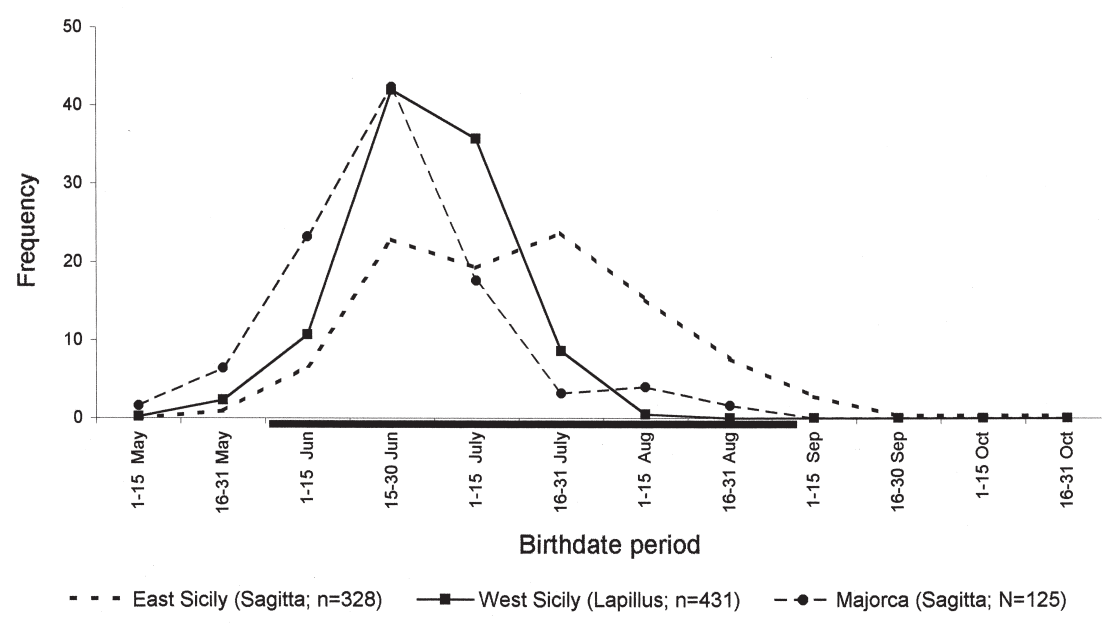

FIG. 7. - Hatchdate distribution back-calculated from the date of capture and the age determined from sagittae for two areas and methods, and lapilli interpretation. In the x-axis the peak spawning period is indicated (Massutí and Morales-Nin, 1997).

increased scatter with FL and a convex upwards trend, mainly the data from the Messina University. This corresponds well with the residuals of a linear relationship of age-length data following a von Bertalanffy growth model. The comparison of the slopes from the linear regressions between age and FL (Table 3), showed differences between all data sets, except for males from Majorca and East Sicily. The origin ordinate (a) was significant in all data sets, although the correlations were relatively high in all cases.

The age interpretation of juvenile fish using daily growth increments in the otoliths (sagittae and lapilli) was tested for precision. The birth-date distribu- 

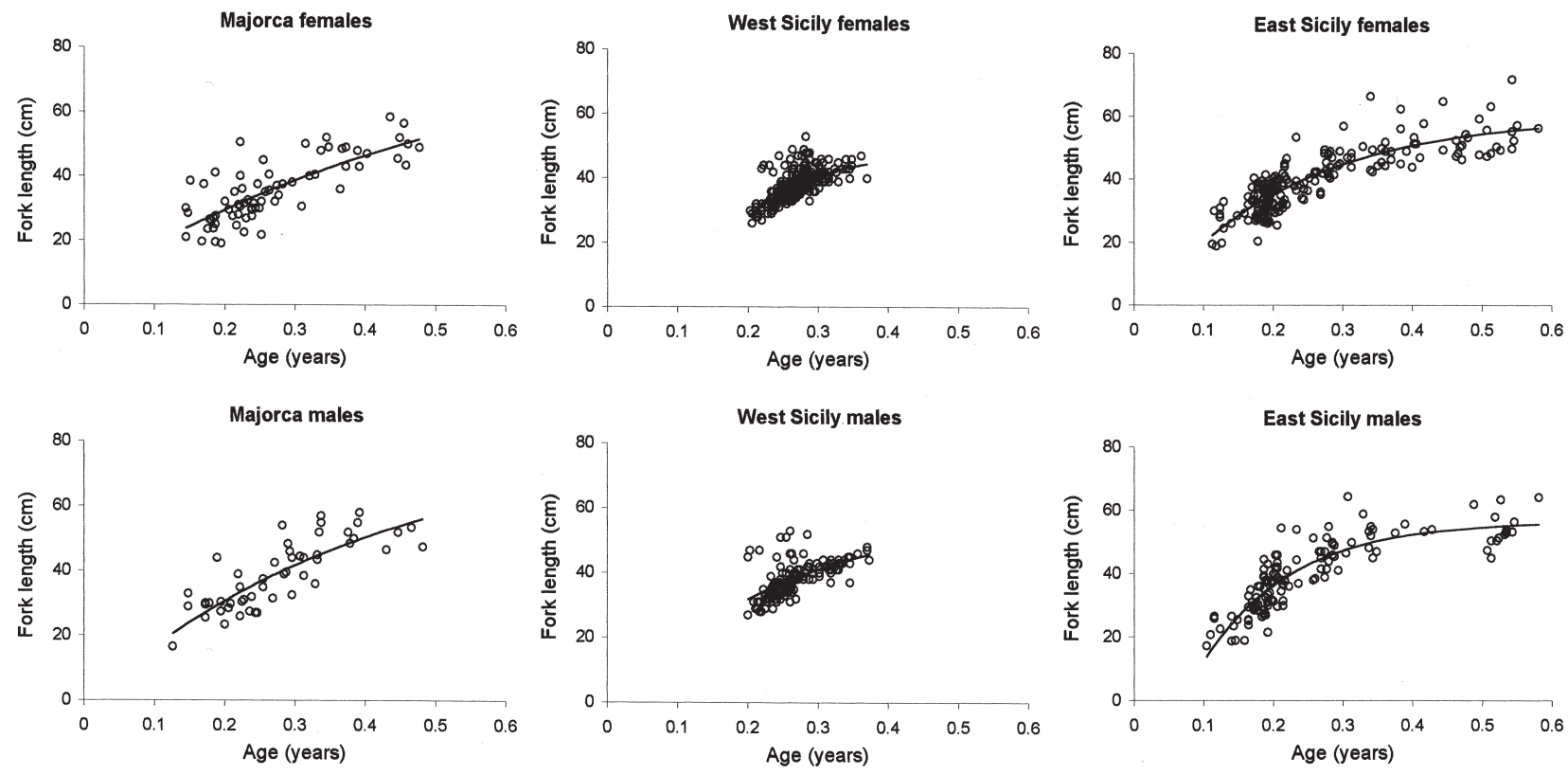

FIG. 8. - Von Bertalanffy growth curves determined for each sex and area.

tion was calculated by subtracting the age in days from the date of capture, since dolphinfish increments are formed from hatching day with daily periodicity (Massutí et al., 1999). It showed a long hatching period, with a peak in the second fortnight of June, and a secondary one in the second fortnight of July for Messina University data (Fig. 7).

The growth curves calculated by sex and area showed a good fit (Fig. 8). Although the estimated growth parameters were different between areas (Table 4), the growth performance index was similar, with small differences between areas and sex. However, the growth parameters were only indicative because the age range was only for juvenile age 0 fish.

\section{DISCUSSION}

The enumeration of growth increments deposited in vertebral centra has been used to age elasmobranchs and tuna. Their annual nature has been validated on sharks (Smith, 1984; Gruber and Stout, 1983), rays (Holden and Vince, 1973) and bluefin tuna (Cayré and Diouf, 1983). The smaller vertebral increments, used in this study to assess dolphinfish age, are apparently laid down with a slightly lower, but significantly different, periodicity than the increments found in the otoliths. This is the first evidence of a higher periodicity than seasonal in the increment formation of vertebrae. Further studies with marked fish
TABLE 4. - Von Bertalanffy growth parameters determined for each area. The standard error of the estimates is between brackets. $\Phi$ : growth performance index (Munro and Pauly, 1983).

\begin{tabular}{lcccc}
\hline \multicolumn{5}{c}{ Females } \\
Area & $\mathrm{L}_{\infty}(\mathrm{cm})$ & $\mathrm{K}\left(\mathrm{yr}^{-1}\right)$ & $\mathrm{t}_{0}$ & $\Phi$ \\
\hline Majorca & $87.75(61.53)$ & $1.71(2.15)$ & $-0.039(0.09)$ & $4.121(0.82)$ \\
Eats Sicily & $60.84(3.0)$ & $4.71(0.85)$ & $0.015(0.02)$ & $4.242(0.13)$ \\
West Sicily & $48.26(4.17)$ & $9.94(3.79)$ & $0.112(0.03)$ & $4.364(0.19)$ \\
\hline \multicolumn{5}{c}{ Males } \\
Parameter & $\mathrm{L}_{\infty}(\mathrm{cm})$ & $\mathrm{K}\left(\mathrm{yr}^{-1}\right)$ \\
\hline Majorca & $81.59(36.79)$ & $2.45(2.17)$ & $0.007(0.06)$ & $4.212(0.56)$ \\
East Sicily & $56.74(1.75)$ & $7.78(0.98)$ & $0.068(0.01)$ & $4.399(0.09)$ \\
West Sicily & $58.25(22.18)$ & $4.313(5.05)$ & $0.016(0.12)$ & $4.165(0.61)$ \\
& & & & $\Phi$ \\
\hline
\end{tabular}

might allow the periodicity of increment formation to be determined and the feasibility of this method to be verified.

An overwhelming percentage of age and growth studies have used the sagittae, because they are generally the largest of the three otoliths and therefore the easiest to extract and examine (Irie, 1960; Campana and Neilson, 1985; Morales-Nin, 1992). References for the lapillus are not very common in the literature and are related to the age determination of larvae and early development stages of juvenile fish (Bailey and Stehr, 1988; Brothers and McFarland, 1981; David et al., 1994).

Daily increment formation starting on the day of birth has been proved for dolphinfish sagittae using reared and wild fish (Uchiyama et al., 1986; Massutí 
et al., 1998). Although the daily nature of increments has been validated on sagittae, the daily periodicity of the increments in the lapillus cannot yet be considered as validated. Also, increment formation starts at different times in the different otoliths (Campana and Neilson, 1985). Thus, ages derived from the lapillus are indicative but a correction factor may be necessary. However, the dispersion of ages determined from the lapilli is smaller. Also, their shape makes it easier to grind and polish them to obtain a suitable section that covers the whole growth of the fish.

Age estimates from sagittae and lapilli were significantly different (paired t-test, $\mathrm{P}=0.01$ ), except for the sagittae readings of males $(\mathrm{P}>0.05)$. The differences obtained between age readings could be caused by differences in sagittae and lapilli increment formation. However, the ages in males were the same using both structures. This might indicate some methodological limitation due to the lower magnification used for lapilli reading, because males, which have the higher growth rate, should have thicker increments and the thinnest increments could thus also be detected. Experiments with marked or known-age fish would be necessary to verify this method.

However, the back-calculation of hatchdates provided an indirect validation and indication of the accuracy of ages. The variations between results might be due to changes in the spawning peak or to differential mortality (Massutí et al., 1999). Thus, the hatching distribution can be compared with the spawning period of the species in the area, which is known from adult fish maturity data (Massutí and Morales-Nin, 1995; 1997). The agreement between these hatching dates and the above-mentioned available reproduction data supports the daily ages determined in otoliths from wild juvenile fish.

\section{ACKNOWLEDGEMENTS}

This work is a result of two projects sponsored by the EU DG XIV (Biological Studies Ref. 94/031 and 95/73). Mr. J. Moranta and Ms. E. Batanero (IMEDEA) are thanked for their help in data analysis and manuscript typing respectively. Dr. R. L. Radtke (University of Hawaii) provided useful advice on otolith preparation and interpretation during a sabbatical visit to IMEDEA, granted by the Spanish Education Ministry, and Dr. C. Rodgers revised the English version of the manuscript.

\section{REFERENCES}

Bailey, K.M. and C.L. Stehr. - 1988. The effects of feeding periodicity and ration on the rate of increment formation in otoliths of larval walleye pollock Theragra chalcogramma (Pallas). J. Exp. Mar. Bio. Eco., 122: 147-161.

Beardsley, G.L. - 1967. Age, growth and reproduction of the dolphin, Coryphaena hippurus, in the Straits of Florida. Copeia, 1967: 441-451.

Benetti, D.D., E.S. Iversen and A.C. Ostrowski. - 1995. Growth rates of captive dolphin, Coryphaena hippurus, in Hawaii. Fish. Bull., 93: 152-157.

Brothers, E.B. and W.N. McFarland. - 1981. Correlations between otolith microstructure, growth and the life history transitions in newly recruited French grunts (Haemulon flavolineatum (Desmarest) Haemulidae). Rapp. Proc.v. I.C.E.S., 178: 369-374.

Cayré, P.M. and T. Diouf. - 1983. Estimating age and growth of little tunny, Euthynnus alletteratus, off the coast of Senegal, using dorsal fin spines. In: E.D. Prince and L.M. Pulos (eds.), Proceedings of the International Workshop on Age Determination of Oceanic Pelagic Fishes: Tunas, Billfishes and Sharks. NOAA Tech. Rep. NMFS, 8: 105-110.

Campana, S.E. and J.D. Neilson. - 1985. Microstructure of fish otoliths. Can. J. Fish. Aquat. Sci., 42: 1014-1032.

David, A.W., J. Jeffery Isely and C.B. Grimes. - 1994. Differences between the sagitta, lapillus, and asteriscus in estimating age and growth in juvenile red drum, Sciaenops ocellatus. Fish. Bull., 92: 509-515.

Gruber S.H. and R.J. Stout. - 1983. Biological materials for the study of age and growth in a tropical marine elasmobranch, the lemon shark Negaprion brevirostris (Poey). In: E.D. Prince and L.M. Pulos (eds.), Proceedings of the International Workshop on Age Determination of Oceanic Pelagic Fishes: Tunas, Billfishes and Sharks. NOAA Tech. Rep. NMFS, 8: 193-205.

Hassler, W.W. and W.T. Hogarth. - 1977. The growth and culture of dolphin, Coryphaena hippurus, in North Carolina. Aquaculture, 12: 115-122.

Hoenig, J.M., M.J. Morgan and C.A. Brown. - 1995. Analysing differences between two age determination methods by tests of symmetry. Can. J. Fish. Aquat. Sci., 52: 364-368.

Holden, M.J. and M.R. Vince. - 1973. Age validation studies on the centra of Raja clavata using tetracycline. Cons. Int. Explor. Mer, 35(1): 13-17.

Irie, T. -1960 . The growth of the fish otoliths. Jour. Fac. Fish. An. Husb., Hiroshima University, 3: 202-221.

Jereb, P., S. Ragonese, A. Arkhipkin, A. Bonanno, M. Gioiello, M. Di Stefano, U. Morara and M. Bascone. - 1996. Sicilian Channel Squid Stocks: Loligo forbesi Steenstrup, 1856. Project: MED 93/010 - European Community, DG XIV. Final report.

Massutí, E. and B. Morales-Nin. - 1995. Seasonality and reproduction of dolphinfish (Coryphaena hippurus) in the western Mediterranean. Sci. Mar., 59: 357-364.

Massutí E. and B. Morales-Nin. - 1997. Reproductive biology of dolphinfish (Coryphaena hippurus L.) off the island of Majorca (western Mediterranean). Fish. Res., 30: 57-65.

Massutí E., B. Morales-Nin and J. Moranta - 1999. Otolith microstructure, age and growth patterns of dolphinfish (Coryphaena hippurus) in the western Mediterranean. Fish. Bull. U. S., 97: 891-899.

Morales-Nin, B. - 1992. Determination of growth in bony fishes from otolith microstructure. FAO Fish. Tech. Pap., 322: 51 pp.

Munro, J.L. and D. Pauly, 1983. A simple method for comparing the growth of fishes and invertebrates. Fishbyte, 1: 5-6.

Murray, P.A. - 1985. Growth and mortality in the dolphinfish Coryphaena hippurus caught off Saint Lucia, W.I. FAO Fish. Rep., 327: 47-153.

Ostrowski, A.C., C. Brownell and E.O. Duerr. - 1989. Growth and feeding rates of juvenile dolphins (Coryphaena hippurus) fed a practical diet through growout. World Aquacult., 20: $104-105$.

Oxenford, H.A. and W. Hunte. - 1983. Age and growth of dolphin, Coryphaena hippurus, as determined by growth increments in otoliths. Fish. Bull., 84: 906-909.

Prager, M.H., S.B. Saila and C.W. Recksiek. - 1987. FISHPARM: A microcomputer program for parameter estimation of non-linear models in fishery science. Old Dominion University Res. Found. Tech. Rep., 87-10: 37 pp. 
Rose, C.D. and W.W. Hassler. - 1968. Age and growth of the dolphin, Coryphaena hippurus (Linnaeus), in North Carolina waters. Trans. Am. Fish. Soc., 97: 271-276.

Smith, S.E. - 1984. Timing of vertebral increments deposition in tetracycline injected leopard sharks. Trans. Am. Fish. Soc., 113: 308-313.

Spratt, J.D. - 1978. Age and growth of the market squid, Loligo opalescens Berry, in Monterey Bay. Fish. Bull. Dept. Fish and Game, Calif., 169: 35-44.

Szyper, J.P., R. Bourke and L.D. Conquest. - 1984. Growth of juvenile dolphinfish, Coryphaena hippurus, on test diets differing in fresh and prepared components. J. World. Maricult. Soc., 15: 219-221.

Torres, F. and D. Pauly. - 1991. Tabular data on marine fishes from Southern Africa, Part II: Growth Parameters. Fishbyte, 9: 37-38.

Uchiyama, J.H., R.K. Burch and S.A. Kraul. - 1986. Growth of dolphins, Coryphaena hippurus and C. equiselis, in Hawaiian waters as determined by daily increments on otoliths. Fish. Bull., 84: 186-191.

Wang, C.H. - 1979. A study of population dynamics of dolphinfish (Coryphaena hippurus) in waters adjacent to Eastern Taiwan. Acta Oceanogr. Taiwan., 10: 233-251. 